\title{
Experimental Identification of Immuno- dominant B-cell Epitopes from SARS-CoV-2
}

\author{
Lluc Farrera-Soler $\S^{\star}$, Jean-Pierre Daguer, Sofia Barluenga, and Nicolas Winssinger \\ §SCS-Metrohm award for best oral presentation in Medicinal Chemistry \& Chemical Biology
}

\begin{abstract}
Severe acute respiratory syndrome coronavirus-2 (SARS-CoV-2) is responsible for the current public health crisis with devastating consequences to our societies. This COVID-19 pandemic has become the most serious threat to global public health in recent history. Given the unprecedented economic and social impact that it is causing, identification of immunodominant epitopes from SARS-CoV-2 is of great interest, not only to gain better insight into the adaptive immune response, but also for the development of vaccines, treatments and diagnostic tools. In this review, we summarize the already published or preprinted reports on the experimental identification of B-cell linear epitopes of SARS-CoV-2 proteins. Six different epitopes leading to neutralizing antibodies have been identified. Moreover, a summary of peptide candidates to be used for diagnostic tools is also included.
\end{abstract}

Keywords: Antibodies $\cdot$ COVID-19 $\cdot$ Epitope $\cdot$ Immunodominant $\cdot$ SARS-CoV-2

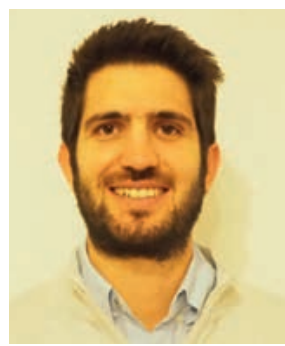

Lluc Farrera-Soler has a Chemistry degree from the University of Barcelona (2014). Financed by an Alfred Werner Scholarship (SCS Foundation), in 2015 he carried out a MSc in Chemical Biology from the National Centre of Competence in Research (NCCR) in Chemical Biology (a collaboration between the University of Geneva and the EPFL) and he is now finishing his doctoral studies at the University of Geneva, in the laboratory of Prof. Nicolas Winssinger. During his Master studies, he became interested in drug discovery and his actual research is based on the discovery and application of new methodologies using peptide nucleic acid (PNA) as a robust analogue of DNA, and most precisely the applications of PNAencoded libraries.

\section{Introduction}

A novel infectious disease attributed to a coronavirus was first reported in late 2019 (COVID-19). [1] Within months, this infectious disease caused by the severe acute respiratory syndrome coronavirus-2 (SARS-CoV-2) had reached enough countries to be declared a pandemic by the World Health Organization (WHO). The magnitude of the pandemic led to unprecedented measures to contain the propagation. Nonetheless, one year later, it has infected $>100$ million people and caused $>2$ million deaths (https:// coronavirus.jhu.edu/map.html) with catastrophic economic and social repercussions in most countries. ${ }^{[2]}$

SARS-CoV-2 belongs to the betacoronavirus family and has high homology to SARS-CoV (79\% sequence identity[3]), the virus responsible for the 2002-2004 outbreak. ${ }^{[4]}$ Based on this homology it was rapidly established that the spike protein, which protrudes from the surface of the viral particles, is responsible for host cell recognition and entry through its interaction with angiotensin-converting enzyme 2 (ACE-2). ${ }^{[5,6]}$ Furthermore, anti- bodies binding to the spike protein of SARS-CoV were known to be sufficient to neutralize the virus, ${ }^{[7]}$ thus bringing attention to the immune response against the spike protein.

The identification of immunodominant linear epitopes on SARS-CoV-2 has been of great interest from the beginning of the outbreak for their obvious potential uses (Fig. 1). Initially, the most urgent issue was the detection of the infection, thus the development of rapid and robust serological assays. ${ }^{\left[{ }^{8]}\right.}$ If one of the detected epitopes is concurrent amongst all infected patients, the selected peptide can be used in rapid serological tests avoiding the use of the whole protein, which is more expensive and less stable than a shorter peptide. Furthermore, a peptide with low homology to other common coronaviruses, such as the ones responsible for common colds, can lead to higher specificity of the test. ${ }^{[9]}$ Understanding which parts of a protein lead to neutral-

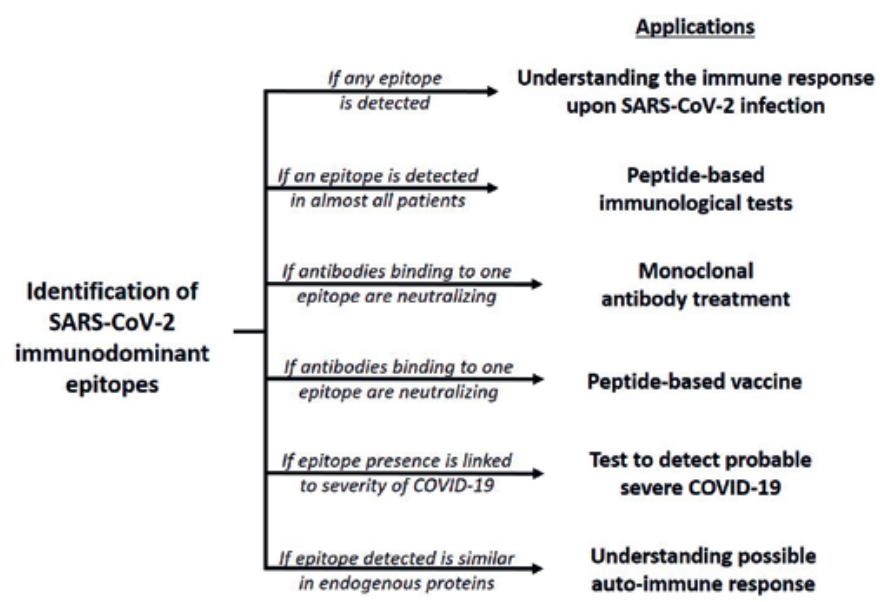

Fig. 1. Applications for the identification of immunodominant epitopes in SARS-CoV-2. 
izing antibodies or binding-only antibodies is important for vaccine development. Finally, if a correlation between a biomarker and severity of the disease is identified, this can provide important prognostic information and patient stratification.

This review summarizes the work done by several groups on the experimental identification of immunodominant B-cell linear epitopes of SARS-CoV-2 proteins and its comparison to the ones found in SARS-CoV.

\section{Experimental Epitope Mapping of SARS-CoV-2 Proteins}

The viral infection of SARS-CoV-2 in humans is characterized by an antibody response which mostly targets the nucleocapsid (N) and spike (S) proteins. ${ }^{[10]}$ In this review, a major emphasis has been given to the epitopes found on the spike protein since they can induce neutralizing antibodies which inhibit host cell recognition and entry.

There are five primary classes of antibodies (IgG, IgM, IgA, $\operatorname{IgD}$, and $\operatorname{IgE}$ ), with $\operatorname{IgG}$ being the most abundant in blood.[11] The onset of IgM production is faster compared to IgG, and that makes it a good candidate for detecting ongoing infection, however, IgMs are not detectable before the onset of symptoms and thus its detection has little value in breaking the chain of transmission. Furthermore, IgM concentration decreases quicker than IgG, making IgG more interesting for the detection of a past infection. ${ }^{[8,12]}$

\subsection{Methodologies}

Different technologies have been used to profile the epitopes of the antibody response (Fig. 2 and Table 1). The experimental techniques involve: 1) microarray-based technologies (Fig. 2a), [13] 2) ELISA-based assays (Fig. 2b) ${ }^{[14]}$ and 3) genetically-encoded technologies (Fig 2c). ${ }^{[15-17]}$ Microarray technologies are based on the immobilization of unique peptides in each spot of a microarray, followed by the addition of patient plasma and a subsequent detection of the antibodies developed by the immune system of the patient with a fluorescently labelled secondary antibody which recognizes the Fc corresponding to the specific class of antibody of interest $(\operatorname{IgM}, \operatorname{IgG}, \ldots)$. Several methodologies have been used for the immobilization of the peptides onto the micro- arrays: (i) spotting biotinylated peptides into a streptavidin coated microarray, ${ }^{[18,19]}$ (ii) spotting peptide-BSA conjugates, ${ }^{[20-22]}$ (iii) hybridizing of peptide-PNA conjugates into DNA microarrays, [23] (iv) spotting alkyne-tagged peptides that are immobilized by CuAAC into an azide-coated microarray, ${ }^{[24]}$ (v) by directly printing the peptide into the microarray ${ }^{[25,26]}$ and other non-disclosed methodologies (performed by CRO). ${ }^{[27-30]}$ For the ELISA-based approaches, Poh et al. (vi) firstly made pools of 5-8 different peptides to identify pools of candidates and refine further analysis of singleton peptides in a deconvolution step, ${ }^{[31,32]}$ whereas Zhang et al. (vii) directly analyzed all the peptides individually. ${ }^{[33]}$ For the genetically-encoded technologies, two different methodologies have been used. On one hand, Ladner et al. (viii) synthesized peptide-DNA conjugates, selected the ones binding to antibodies from plasma and further deconvoluted by sequencing. ${ }^{[34]}$ On the other hand, some groups (ix) used the phage-display immunoprecipitation sequencing (PhIP-Se) strategy ${ }^{[35-38]}$ in which different peptides are expressed on the surface of a bacteriophage and sequenced the ones binding to plasma antibodies. ${ }^{[39-43]}$ Finally, Zamecnik et al. (x) have merged two different technologies by first doing a bacteriophage selection and further immobilizing the hits into a microarray. ${ }^{[44]}$

As can be observed in Table 1, different groups have used different methodologies, peptide lengths and covered different parts of the human Coronavirus (hCoVs) proteome. Nonetheless, despite all these differences, common epitopes have been identified across the different reports even if a direct comparison is unwarranted due to the differences among the protocols used (antibody loading, statistical analysis, etc.) and in the criteria used for considering an epitope as relevant. For instance, some studies preferred to focus on epitopes with at least one patient showing very strong signal, whereas others focused on epitopes that were preponderant across multiple patients. In order to balance all these biases, as well as a possible demographic bias, this review will focus on the most frequently highlighted epitopes among different studies.

The previously mentioned approaches present some limitations. First of all, the analysis is limited to linear epitopes and therefore all antibodies binding to a non-linear epitope might a) Microarray

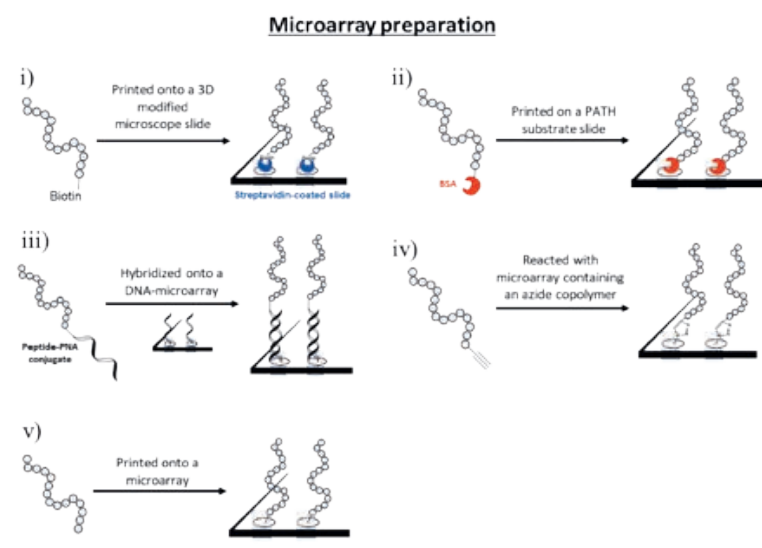

Microarray screening b) ELISA

vi)

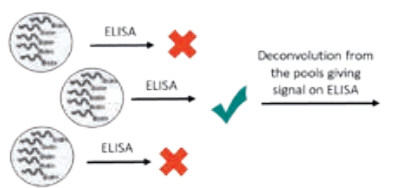

vii)

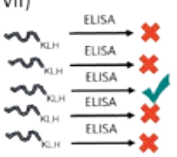

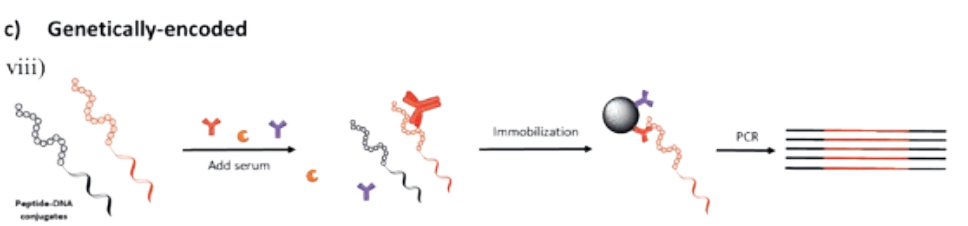

ix)

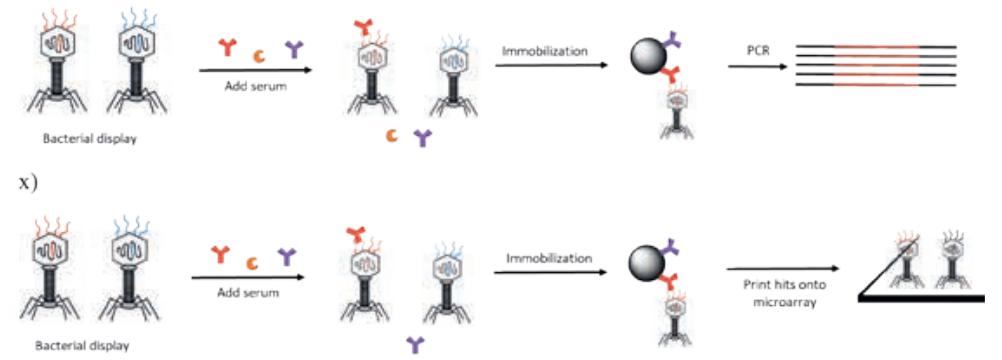

Fig. 2. Technologies used to experimentally identify linear epitopes on SARS-CoV-2 proteins. a) Microarray, b) ELISA and c) Genetically-encoded. 
Table 1. Summary of the different methodologies used among the reviewed manuscripts.

The manuscripts have been ordered by day of publication of the preprint.

\begin{tabular}{|c|c|c|c|c|}
\hline Manuscript & Methodology & Peptide length & Studied proteins & + Samples \\
\hline Wang et al. ${ }^{[18]}$ & Peptide microarray & 15 & SARS-CoV-2 proteome & 10 \\
\hline Poh et al..$^{[31]}$ & ELISA & 18 & S protein SARS-CoV-2 & 6 \\
\hline Dahlke et $a l .{ }^{[30]}$ & Peptide microarray & 15 & SARS-CoV-2 proteome & 4 \\
\hline Zhang et al..$^{[33]}$ & ELISA & $20-25$ & S protein SARS-CoV-2 & 39 \\
\hline Zhang et al..$^{[19]}$ & Peptide microarray & 15 & SARS-CoV-2 proteome & 15 \\
\hline Zamecnkick et al..$^{[44]}$ & $\begin{array}{l}\text { PhIP-Se, VirScan }+ \\
\text { Phage display microarray }\end{array}$ & 38 & Proteome different hCoVs & 20 \\
\hline Amrun et al..$^{[32]}$ & ELISA & 18 & $\begin{array}{l}\text { S, E, } M \text { and } N \text { proteins } \\
\text { SARS-CoV-2 }\end{array}$ & 18 \\
\hline $\mathrm{Li}$ et al. ${ }^{[20]}$ & Peptide microarray & 12 & S protein SARS-CoV-2 & 55 \\
\hline Farrera et al..$^{[23]}$ & Peptide microarray & 12 & S protein SARS-CoV-2 & 12 \\
\hline Shrock et al. ${ }^{[39]}$ & PhIP-Se, VirScan & 56 & Proteome different hCoVs & 550 \\
\hline Li et al..$^{[21]}$ & Peptide microarray & 12 & S protein SARS-CoV-2 & 1,051 \\
\hline Ladner et al. $^{[34]}$ & DNA-encoded & 30 & Proteome different hCoVs & 27 \\
\hline Yi et al. ${ }^{[29]}$ & Peptide microarray & 20 & $\begin{array}{l}\mathrm{S}, \mathrm{M} \text { and } \mathrm{E} \text { proteins SARS- } \\
\mathrm{CoV}-2\end{array}$ & 120 \\
\hline Mishra et al..$^{[25]}$ & Peptide microarray & 12 & Proteome different hCoVs & 132 \\
\hline Li et al..$^{[41]}$ & Peptide microarray & 12 & S protein SARS-CoV-2 & 858 \\
\hline Wang et al..$^{[40]}$ & PhIP-Se, VirScan & $56 / 28$ & Virome & 156 \\
\hline Qi et al. ${ }^{[41]}$ & PhIP-Se / AbMap ${ }^{[38]}$ & Random & Random & 55 \\
\hline Klompus et al..$^{[42]}$ & PhIP-Se, VirScan & $64 / 20$ & Proteome different hCoVs & 32 \\
\hline Musico et al..$^{[24]}$ & Peptide microarray & 15 & SARS-CoV-2 proteome & 19 \\
\hline Haynes et al. ${ }^{[43]}$ & PhIP-Se / SERA ${ }^{[37]}$ & Random & Random & 779 \\
\hline Holenya et al. ${ }^{[26]}$ & Peptide microarray & 15 & Proteome different hCoVs & 24 \\
\hline Heffron et al. ${ }^{[27]}$ & Peptide microarray & 16 & Proteome different hCoVs & 40 \\
\hline Camerini et al..$^{[28]}$ & Peptide microarray & $100 / 50 / 30$ & Proteome different hCoVs & 20 \\
\hline
\end{tabular}

be overlooked. Second, it does not replicate epitopes with posttranslational modifications such as glycosylations. ${ }^{[45]}$ Third, most of the analyses do not consider the emergence of different strains (https://www.gisaid.org/) with a variety of mutations that could account for regional variations.

\subsection{Ig G Epitope Mapping of the Spike Protein S1 Subunit (Amino Acids 1-685)}

The S1 subunit of the spike protein comprises the receptor binding domain (RBD, amino acids 306-527). The RBD is responsible for the interaction with ACE-2 and therefore, antibodies binding to it are of great interest for their potential neutralizing activity by outcompeting the virus-host interaction. ${ }^{[46-48]}$ The most frequently detected epitope on the RBD is the S450-499 (Table 2). This epitope is found exactly on the RBD-ACE2 recognition site (Fig. 3B). Immunizing mice with this peptide has yielded neutralizing antibodies ${ }^{[33]}$ and also an antibody binding to this peptide has been previously shown to have neutralizing activity. ${ }^{[49]}$ Next to the RBD appears another immunodominant peptide (S550-593), which has also been shown to be able to generate neutralizing activity. ${ }^{[20,29,31]}$ This neutralizing activity has been hypothesized to be caused either by sterically blocking the binding of ACE- 2 or through an allosteric effect on the ACE-2 binding. Even though the RBD is known to be highly immunogenic, ${ }^{[10,50]}$ not many linear epitopes have been detected on that part of the protein. This is probably due to the fact that most of the antibodies binding to the RBD bind to non-linear epitopes. This is consistent with the work of Li et al. and our own work, in which we show that a known RBD-binding antibody binds poorly to a linear epitope.[21,23]

Two additional interesting epitopes are detected at the C-terminus of the S1 subunit (S625-636 and S655-672). These two epitopes are in close proximity to the $\mathrm{S} 1 / \mathrm{S} 2$ cleavage site (Fig. $3 \mathrm{C})$, which has been shown to be critical for viral infection. ${ }^{[51,52]}$ Antibodies binding to this area have a big potential for therapeutics as shown by Li et al., who reported antibodies binding to the S625-636 peptide with neutralizing activity, ${ }^{[20]}$ and from our own work in which we reported that plasma containing antibodies binding to the S655-672 epitope inhibit the furin-mediated proteolysis of spike whereas plasma that is negative for this epitope does not inhibit this proteolysis. ${ }^{[23]}$

\subsection{IgG Epitope Mapping of the Spike Protein S2 Subunit (Amino Acids 686-1273)}

The $\mathrm{S} 2$ subunit of the spike protein contains some of the key players for cell entry such as the fusion peptide (S788-806), the S2 cleavage site (S815-816), and the two heptad repeats named HR1 (S912-984) and HR2 (S1163-1213). ${ }^{[53,54]}$

The most observed immunological epitope on this subunit is the S765-835 (Fig. 3D). It comprises the fusion peptide and the $\mathrm{S} 2$ cleavage site, and antibodies binding to that epitope 
have shown neutralizing activity both in SARS-CoV-2 ${ }^{[31]}$ and in SARS-CoV. ${ }^{[55]}$ Among this region, peptide S812-829 is highly homologous between all the coronavirus, and almost identical among SARS-Cov-2, SARS-Cov and BtCoV-RaTG13.[21] If this peptide can elicit strong neutralization activity, it could serve as a promising candidate for making a broad neutralizing antibody and vaccine.

Another epitope frequently detected in the S2 subunit is the S1140-1178 (Fig. 3E). This epitope contains part of the HR2, and antibodies binding to that peptide have also shown neutralizing activity. ${ }^{[20,29]}$ It has been hypothesized that antibodies binding to this epitope may interfere with conformational changes essential for effective virus-cell fusion. ${ }^{[56]}$ This neutralizing activity is consistent with the observed fusion inhibition activity of different peptides and antibodies targeting either the HR1 or HR2 on previous coronavirus. ${ }^{[57-64]}$

Finally, the very last peptide on the C-terminus of the spike protein (S1247-1273) has also shown to be highly immunogenic.

\subsection{Epitope Mapping of Other Proteins of the SARS- CoV-2 Proteome}

Whereas many of the reports have only focused on the spike protein, some other groups have also mapped the epitope profile of the whole SARS-CoV-2 proteome (Table 1). With fewer or no expectations of finding neutralization, the main interest in mapping all the proteins in the virus is to better understand the immune response and to see if any epitope could be used for diagnostics. Of special interest are the epitopes found on the $\mathrm{N}$ protein for its high immunogenic profile ${ }^{[10,65]}$ and also because this protein has been extensively used in serological tests. ${ }^{[66-68]}$ As can be observed in Table 2, the most frequently identified epitopes on the N protein are N140-193, N206-261 and N362-420. Other identified epitopes were the M1-24 in the membrane protein and Orf3a-176-210 in the Orf3a protein. The epitopes from other proteins showed less reproducibility.

\section{Applications}

\subsection{Neutralizing Antibodies for Therapeutics and Design of Vaccines}

Engineered antibodies are increasingly used as therapeutics, ${ }^{[69]}$ and application of antibody-based therapies for COVID-19 are expected to be approved. Two different antibody-based treatments have already received the emergency use authorization by the FDA and many more are in clinical trials. ${ }^{\left[{ }^{[0]}\right.}$ However, the majority of those antibodies target the same region of the virus (the RBD), and putting the focus in only one region could be risky since evolutionary pressure on a particular part of the protein may cause potential mutations which could finally reduce the effectiveness of the RBD-focused therapeutics. ${ }^{[71]}$ The same can be said for the RBD-based vaccines which will only induce the production of antibodies binding to the RBD. For this reason, the identification of other regions of the virus which can elicit neutralizing antibodies is critical.

Table 2. List of immunodominant detected epitopes on SARS-CoV-2 proteome from the reviewed manuscripts. Manuscripts published by the same corresponding author have been combined (two from Prof. X. Yu, ${ }^{[18,19]}$ two from Prof. L. F. P. Ng, ${ }^{[31,32]}$ and four from Prof. S. C. Tao, ${ }^{[20-22,41]}$ ). The numeration of each epitope is based on the following protein sequences: Spike protein (GenBank: QHD43416.1), N protein (GenBank: BCN28213.1), M protein (UniProtKB/Swiss-Prot: PODTC5.1), Orf1ab (GenBank: QLJ57697.1), Orf3a (GenBank: BCI50534.1), Orf7a (UniProtKB/Swiss-Prot: PODTC7.1) and Orf8 (UniProtKB/Swiss-Prot: PODTC8.1). Some nearly adjacent epitopes within the same manuscript have been merged for an easier visualization of the table.

\begin{tabular}{|c|c|c|c|c|c|c|c|c|c|c|c|c|c|c|c|c|c|}
\hline $\begin{array}{l}\text { Wang/ } \\
\text { Zhang } \\
{[18,19]}\end{array}$ & $\begin{array}{c}\text { Poh/ } \\
\text { Amrun } \\
{[31,32]}\end{array}$ & $\begin{array}{c}\text { Dahlke } \\
{[30]}\end{array}$ & $\begin{array}{c}\text { Zhang } \\
\text { [33] }\end{array}$ & $\begin{array}{c}\text { Zamecnik } \\
{[44]}\end{array}$ & $\begin{array}{c}\mathbf{L i} / \mathbf{Q i} \\
{[20-22,41]}\end{array}$ & $\begin{array}{c}\text { Farrera } \\
\text { [23] }\end{array}$ & $\begin{array}{c}\text { Shrock } \\
\text { [39] }\end{array}$ & $\begin{array}{c}\text { Ladner } \\
\text { [34] }\end{array}$ & $\begin{array}{c}\mathbf{Y i} \\
{[29]}\end{array}$ & $\begin{array}{c}\text { Mishra } \\
\text { [25] }\end{array}$ & $\begin{array}{c}\text { Wang } \\
{[40]}\end{array}$ & $\begin{array}{c}\text { Klompus } \\
{[42]}\end{array}$ & $\begin{array}{c}\text { Musico } \\
\text { [24] }\end{array}$ & $\begin{array}{c}\text { Haynes } \\
{[43]}\end{array}$ & $\begin{array}{c}\text { Holenya } \\
{[26]}\end{array}$ & $\begin{array}{c}\text { Heffron } \\
{[27]}\end{array}$ & $\begin{array}{c}\text { Camerini } \\
{[28]}\end{array}$ \\
\hline \multicolumn{18}{|c|}{ SPIKE PROTEIN ---- SPIKE PROTEIN ---- SPIKE PROTEIN ---- SPIKE PROTEIN ---- SPIKE PROTEIN ---- SPIKE PROTEIN ---- SPIKE PROTEIN } \\
\hline 26-30 & & & $21-45$ & & 25-36 & & & & & & & & $79-83$ & & & & \\
\hline \multirow[t]{2}{*}{ 186-190 } & 209-226 & & $221-285$ & & & & & & & & & & & & & & \\
\hline & & & $330-349$ & & & & & & & & & & & & & & \\
\hline $356-360$ & & 369-383 & $375-394$ & & & & & & & & & & & & & & \\
\hline \multirow{5}{*}{$456-460$} & & & $450-499$ & & & & & & & & & & 459-487 & & & & \\
\hline & $553-570$ & & $522-646$ & $552-589$ & $550-612$ & & $550-570$ & 543-589 & $554-593$ & 553-591 & & $529-593$ & & $555-572$ & $557-567$ & $549-593$ & $551-650$ \\
\hline & & $637-651$ & $522-646$ & & $625-642$ & & & & & $607-633$ & & & & & & $624-646$ & \\
\hline & & & & & 661-684 & $655-672$ & & & $654-673$ & $671-706$ & & & $671-685$ & & $661-671$ & $685-709$ & \\
\hline & 769-786 & $725-739$ & & $799-855$ & $764-805$ & $787-822$ & $785-805$ & $795-848$ & & $765-827$ & $785-840$ & $749-857$ & & & 789-799 & $785-832$ & $736-835$ \\
\hline $806-820$ & $809-826$ & $811-831$ & & $799-855$ & $804-829$ & $787-822$ & $810-830$ & $795-848$ & $806-825$ & $765-827$ & $785-840$ & $749-857$ & & $810-818$ & $813-823$ & $785-832$ & $736-835$ \\
\hline \multirow[t]{2}{*}{$886-890$} & & 927-955 & 902-906 & & & & & $971-1006$ & & & & & & & & & 886-1035 \\
\hline & & & & $1141-1178$ & 1148-1159 & $1147-1158$ & $1146-1166$ & $1127-1177$ & 1146-1165 & $1143-1177$ & 1093-1176 & $1101-1209$ & & $1145-1159$ & 1145-1159 & $1140-1164$ & 1086-1235 \\
\hline 1196-1200 & & 1201-1217 & & & $1256-1273$ & & $1250-1270$ & & & & & & & & $1259-1271$ & $1247-1273$ & \\
\hline \multicolumn{18}{|c|}{ NUCLEOCAPSID PROTEIN ---- NUCLEOCAPSID PROTEIN ----NUCLEOCAPSID PROTEIN ---- NUCLEOCAPSID PROTEIN ---- NUCLEOCAPSID PROTEIN } \\
\hline $86-110$ & & & & & & & & & & & & $89-153$ & & & $13-23 / 37-47$ & $28-55$ & \\
\hline $166-170$ & $153-170$ & $176-206$ & & $134-190$ & & & 161-181 & $140-193$ & & & 141-196 & $133-197$ & $156-170$ & $158-172$ & $161-171$ & & \\
\hline 206-210 & & & & $210-247$ & & & $222-260$ & & & $228-261$ & & $221-285$ & 284-298 & & $221-231$ & $208-266$ & $201-300$ \\
\hline 366-375 & & $366-406$ & & $362-399$ & & & $365-406$ & & & $370-416$ & & $353-420$ & & $380-419$ & $377-407$ & $384-416$ & $301-419$ \\
\hline \multicolumn{18}{|c|}{ OTHER PROTEINS ---- OTHER PROTEINS ---- OTHER PROTEINS ---- OTHER PROTEINS ---- OTHER PROTEINS ---- OTHER PROTEINS ---- OTHER PROTEINS } \\
\hline $\begin{array}{c}\text { Orf1ab } \\
296-300\end{array}$ & & $\begin{array}{c}\mathrm{M} \\
1-7\end{array}$ & & $\begin{array}{c}\text { Orf3a } \\
172-209\end{array}$ & & & $\begin{array}{c}\text { Orf1 } \\
151-171\end{array}$ & & $\begin{array}{c}\mathrm{M} \\
1-19\end{array}$ & $\begin{array}{c}\mathrm{M} \\
185-199\end{array}$ & & $\begin{array}{c}\mathrm{M} \\
159-223\end{array}$ & $\begin{array}{c}\text { Orf1ab } \\
1912-1926\end{array}$ & $\underset{1-12}{M}$ & $\begin{array}{c}\mathrm{M} \\
5-19\end{array}$ & $\begin{array}{c}\mathrm{M} \\
1-24\end{array}$ & $\begin{array}{c}\mathrm{M} \\
1-50\end{array}$ \\
\hline $\begin{array}{c}\text { Orflab } \\
3206-3210\end{array}$ & & $\underset{203-222}{M}$ & & & & & $\begin{array}{c}\text { Of3a } \\
171-210\end{array}$ & & & $\begin{array}{c}\text { Orf1ab } \\
1914-1928\end{array}$ & & $\begin{array}{c}\text { Orf1ab } \\
269-333\end{array}$ & $\begin{array}{c}\text { Orf1ab } \\
2868-2882\end{array}$ & & $\begin{array}{c}\text { Orf1ab } \\
1657-1671\end{array}$ & $\begin{array}{c}\text { M } \\
152-177\end{array}$ & $\begin{array}{c}\mathrm{M} \\
101-200\end{array}$ \\
\hline $\begin{array}{c}\text { Orf3a } \\
136-140\end{array}$ & & & & & & & & & & $\begin{array}{c}\text { Orf1ab } \\
5419-5438\end{array}$ & & & $\begin{array}{c}\text { Orflab } \\
3808-3822\end{array}$ & & $\begin{array}{c}\text { Orf1ab } \\
2153-2167\end{array}$ & $\begin{array}{c}\mathrm{M} \\
181-222\end{array}$ & $\begin{array}{c}\text { Orf3a } \\
201-275\end{array}$ \\
\hline $\begin{array}{c}\text { Orf3a } \\
176-180\end{array}$ & & & & & & & & & & $\begin{array}{c}\text { Orf1ab } \\
6292-6306\end{array}$ & & & $\begin{array}{c}\text { Orflab } \\
4836-4850\end{array}$ & & $\begin{array}{c}\text { Orf3a } \\
261-267\end{array}$ & $\begin{array}{c}\text { Orf1ab } \\
1239-1256\end{array}$ & $\begin{array}{l}\text { Orf7a } \\
1-100\end{array}$ \\
\hline \multirow[t]{2}{*}{$\begin{array}{c}\text { Orf7a } \\
111-121\end{array}$} & & & & & & & & & & $\begin{array}{c}\text { Orf3a } \\
181-203\end{array}$ & & & $\begin{array}{c}\text { Orf1ab } \\
4600-4614\end{array}$ & & & $\begin{array}{c}\text { Orf1ab } \\
4514-4529\end{array}$ & \\
\hline & & & & & & & & & & $\begin{array}{c}\text { Orf8 } \\
66-86\end{array}$ & & & & & & $\begin{array}{c}\text { Orf1ab } \\
5999-6014\end{array}$ & \\
\hline
\end{tabular}



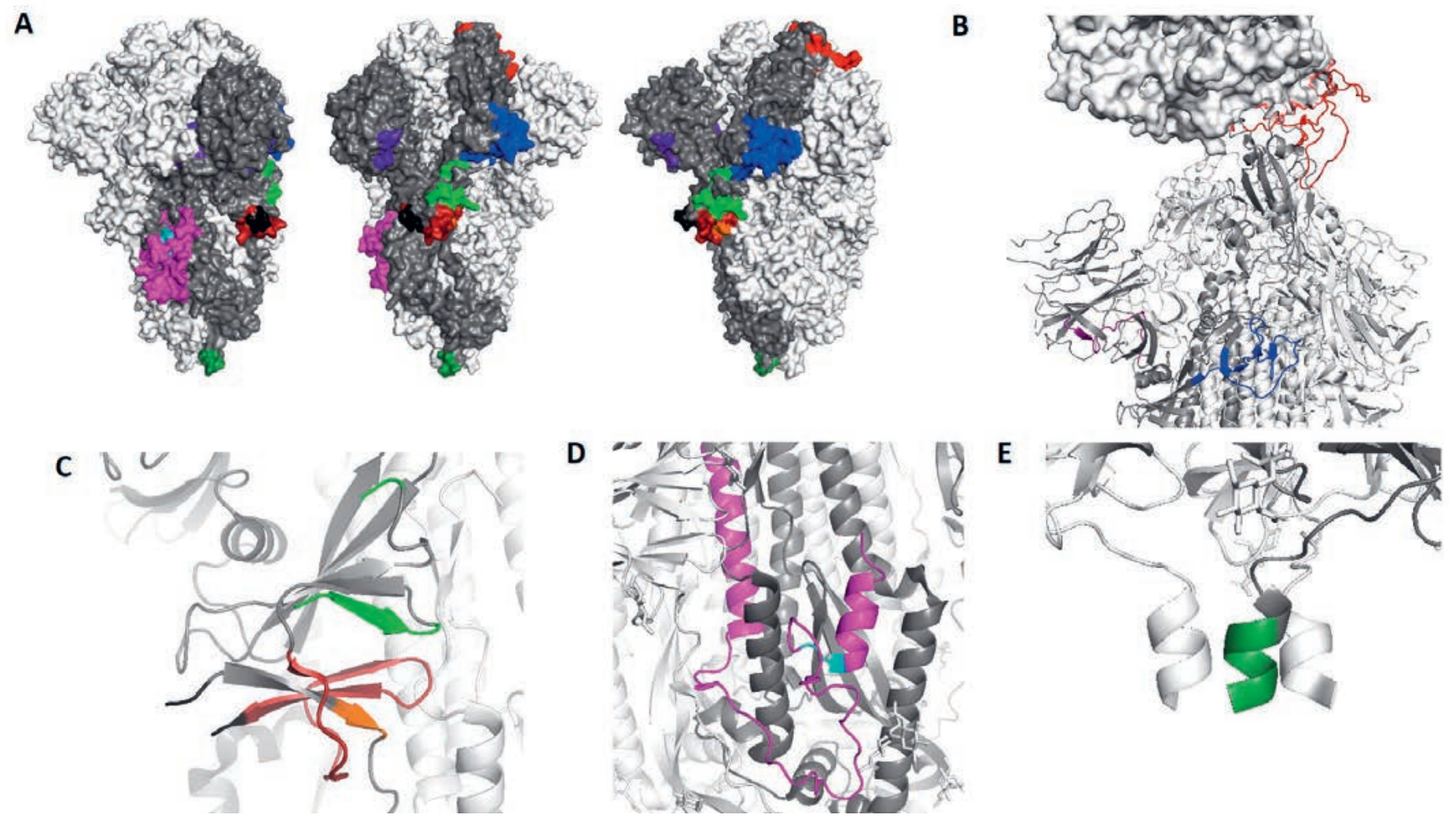

Fig 3. Detailed location of the most frequently detected epitopes A) Three different representations of the spike protein of SARS-CoV-2 in the close state (pdb ID: 6VXX) with one trimer in dark gray and the two rest ones in clear white. The most frequently observed epitopes have been labelled in: 21-45 purple, 450-499 red, 550-593 blue, 654-674 dark red, 675-690 black (S1/S2 furin cleavage site), 619-646 light green, 695-696 orange (S1/S2 cleavage site), 765-830 magenta, 815-816 cyan (S2 cleavage site), and 1143-1147 dark green. Some parts of the protein are not shown in the crystal structure and in this case the two precedent and subsequent amino acids of the non shown peptide have been colored. B) Zoom of the epitopes on the RBD region (pdb Id: 7KNE, 'Cryo-EM structure of single ACE2-bound SARS-CoV-2 trimer spike' in which the spike protein is represented as a cartoon and ACE2 represented as the surface), C) Zoom of the epitopes on the S1/S2 cleavage site area (pdb ID: 6VXX), D) Zoom of the epitopes on the S2 cleavage site area (pdb ID: 6VXX) and E) Zoom of the epitope on the C-terminal region of spike protein (pdb ID: 6VXX).

As summarized in this review, six different epitopes on the spike protein have been reported to lead to neutralizing antibodies (S370-395, ${ }^{[33]} \mathrm{S} 435-479,{ }^{[33]} \mathrm{S} 553-593,{ }^{[20,29,31]} \mathrm{S} 625-636,{ }^{[20]}$ S812-826[31] and S1146-1165[20,29]). Three of them are totally outside the RBD region and have been hypothesized to interfere with S1/S2 cleavage and virus-cell fusion. Nonetheless, more work remains to be done to fully understand the function and future of those antibodies as potential therapeutics and their respective epitopes as potential peptide-based vaccines.

\subsection{Detection Test}

During this last year, testing has been critical to contain the propagation of the virus and analyze the penetration of the infection. Although testing current infected patients is crucial to stop the viral transmission, testing previous infection has also been shown to be important to better understand the global epidemiological situation. In the near future, it might also be important to assess the vaccine-induced immunity on a global level.

While quantitative reverse transcriptase PCR (qRT-PCR) remains the gold standard for early detection of SARS-CoV-2 infected individuals, the decrease of the viral load after infection makes it rapidly unmeasurable. ${ }^{[8]}$ Serological tests, which detect the presence of antibodies in plasma against a particular antigen, are a great candidate to diagnose past infection. Most of the current tests take advantage of the high immunogenicity of the $\mathrm{S}$ and $\mathrm{N}$ protein. ${ }^{[72]}$ However, full-length recombinant proteins present the drawbacks of high cost, possible stability problems, batch-to-batch variations and in some cases may give raise to cross-reactivity (all this leading to ambiguous detection outcomes. ${ }^{[73,74]}$. This cross-reactivity might generate false-positive results as might be the case for SARS-CoV-2 when using proteins sharing high homology with genetically similar, cocirculating, human coronaviruses $(\mathrm{hCoV})$ that are responsible for common colds. Thus, there is an imperative need to develop highly specific and sensitive serology-based tests.

Different groups have proposed distinct peptides as candidates to substitute the aforementioned full-length proteins. Some groups have also suggested a combination of two peptides to overcome the limitation of lower immunogenicity of peptides (compared to full-length protein) and the possible cross-reactivity of the most immunogenic peptides.

The proposed peptides are: S769-786 + N153-170 (Amrun et al. ${ }^{[32]}$ ), N386-406 + S810-830 + S1146-1166 (Shrock et al. ${ }^{[39]}$ ), S1143-1165 (Mishra et al. ${ }^{[25])}$, S1148-1159 + 577-588 (Li et al.[22]), N155-171 (Musico et al.[24]), N377-407/S557567/S789-799 (Holenya et al.[26]) and M1-24 (Heffron et al. ${ }^{[27])}$.

In addition, it might be expected that the immune response can be related to some key clinical parameters, such as gender, age, disease severity, demography,... Different reports have analyzed the difference in epitope profile depending on the severity of COVID-19 infection (especially hospitalized vs nonhospitalized patients) finding some epitopes with a significantly stronger response among the hospitalized patients. $[25,27,30,32,39,43]$ 


\subsection{Mutations on the SARS-CoV-2}

Since the first detection of SARS-CoV-2 in Wuhan (China), new variants acquiring novel mutations have been observed and are slowly replacing the original strains. ${ }^{[75,76]}$ Of special interest are the mutations on the spike protein since these are the ones that can have the biggest impact on the effectivity of the monoclonal antibody therapies and vaccines (since most of them target/use the spike protein). In early February 2020, a new mutation 'D614G' was observed and quickly became the dominant form of the virus circulating globally owing to its increased infectivity and transmission. ${ }^{[75,76]}$ Afterwards, five main new variants have been detected in Denmark (Cluster 5), ${ }^{[77]} \mathrm{UK}$ (B.1.1.7), ${ }^{[78]}$ South Africa (20H/501Y.V2), ${ }^{[79]}$ Brazil (P.1) ${ }^{[80]}$ and southern California (CAL.20C). ${ }^{[81]}$ The mutations found on the spike protein from these strains are as follows. For Cluster 5 (H69-70Vdel, Y453F, I692V, S1147L and M1229I), for B.1.1.7 (H69-70Vdel, Y144del, N501Y, A570D, P681H, T716I, S982A, $\mathrm{D} 1118 \mathrm{H}$ ), for $20 \mathrm{H} / 501 \mathrm{Y} . \mathrm{V} 2$ (L18F, D80A, D215G, L242244Ldel, R246I, K417N, E484K, N501Y, D614G and A701V), for P.1 (L18F, T20N, P26S, D138Y, R190S, K417T, E484K, N501Y, D614G, H655Y, T1027I and V1176F) and finally for CAL.20C (S13I, W152C and L452R). To sum up, several mutations have been observed on the RBD (K417N, L452R, Y453F, E484K and N501Y). Filtering for the mutations that can affect the reported epitopes: A570D (for the S550-570) found in UK (B.1.1.7), H655Y for the (S625-672) found in Brazil (P.1), S1147L for the (S1146-1166) found in Denmark (Cluster 5) and none for the S770-830, confirming that this is one of the most conserved regions of the protein and suggesting that mutation in this region is functionally disadvantageous.

The work done by Haynes et al. ${ }^{[43]}$ and Qi et al., ${ }^{[41]}$ in which they start from a bacteriophage random library (not focused on hCoV proteome), not only allows the profiling of the epitopes at a single amino acid resolution, but also allows the study of how new mutations can affect antibody binding. This has already been applied by Haynes et al. on the new B.1.17 variant. [82]

\section{Comparison to SARS-CoV Epitopes}

In order to better predict the immune protection against a hypothetical future new SARS-CoV, one important exercise is to compare the epitopes found on SARS-CoV-2 to its highly homologous SARS-CoV. Table 3 shows the epitopes detected in previous reports studying experimentally the B-cell response of SARS-CoV at the peptide level. ${ }^{[83-92]}$ The most frequently detected epitopes on SARS-CoV were S532-548, S599-620, S785809, N125-175 and N362-412. Similarly, with SARS-CoV-2, not many linear epitopes were detected on the RBD region. Two highly immunologic regions on SARS-CoV-2 (S550-672 and S765-835) were also detected on SARS-CoV (S532-620 and S785-809), yet the epitope S1140-1178 on SARS-CoV-2 was not detected on the previous SARS-CoV but two adjacent peptides were recognized (S1060-1078 and S1164-1191). He et al. reported the peptide S603-634 as the most immunogenic epitope and supported its applicability for serological tests with a study of 42 patients. ${ }^{[86]}$

\section{Conclusions}

The comparison of 23 experimental reports on the identification of B-cell epitopes on SARS-CoV-2 shows: 1) The presence of highly immunologic epitopes across the S, N, M and Orf3a proteins, 2) Four highly immunodominant regions of the spike protein which lead to neutralizing antibodies (S550-570, S625-636, S812-826 and S1146-1166) and 3) Several peptide candidates for serological tests. The fact that these epitopes were detected using different technologies in different labs lends a high level of confidence in the robustness of these findings.
Table 3. Epitopes experimentally detected on the S, N and M proteins of SARS-CoV. First column represents the numeration on SARS-CoV (genomic sequence UniProtKB/Swiss-Prot: P59594.1 for spike protein, GenBank: ABI96968.1 for N protein and GenBank: AAR86779.1 for M protein). Second column represents the corresponding numeration of the peptide with higher homology on SARS-CoV-2 (genomic sequence GenBank: QHD43416.1 for spike protein, GenBank: BCN28213.1 for N protein and GenBank: PODTC5.1 for M protein), and finally third column is the sequence homology between the SARS-CoV and SARS-CoV-2 sequences. For the epitopes reported by Guo et al., ${ }^{\left[{ }^{83]}\right.}$ only the ones detected in at least 3 patients are detailed below and for Yu et al. ${ }^{[91]}$ only the ones detected in more than four patients.

\begin{tabular}{|c|c|c|}
\hline Epitope SARS-CoV & Epitope SARS-CoV-2 & Seq. homology \\
\hline S9-71 $1^{[86]}$ & S5-67 & $52 \%$ \\
\hline S88-99 $9^{[91]}$ & S91-102 & $75 \%$ \\
\hline $\mathrm{S} 171-224^{[86]}$ & $\mathrm{S} 178-231$ & $56 \%$ \\
\hline $\mathrm{S} 271-318^{[86]}$ & $\mathrm{S} 284-331$ & $69 \%$ \\
\hline $\mathrm{S} 469-882^{[89]}$ & S483-900 & $80 \%$ \\
\hline $\mathrm{S} 471-503^{[87]}$ & S485-517 & $75 \%$ \\
\hline $\mathrm{S} 532-548^{[86,91]}$ & S546-562 & $76 \%$ \\
\hline S599-620 $0^{[86,87,89]}$ & S613-634 & $86 \%$ \\
\hline S651-674 ${ }^{[83]}$ & S665-692 & $65 \%$ \\
\hline S695-708 ${ }^{[83]}$ & S713-726 & $79 \%$ \\
\hline $\mathrm{S} 785-809^{[90,92]}$ & S803-827 & $92 \%$ \\
\hline $\mathrm{S} 842-913^{[86]}$ & S860-931 & $88 \%$ \\
\hline $\mathrm{S} 1060-1078^{[91]}$ & S1078-1096 & $94 \%$ \\
\hline $\mathrm{S} 1164-1191^{[87]}$ & S1182-1209 & $100 \%$ \\
\hline N67-76 $6^{[87]}$ & N66-75 & $100 \%$ \\
\hline $\mathrm{N} 125-175^{[83,85,92]}$ & N124-174 & $90 \%$ \\
\hline $\mathrm{N} 362-412^{[83,85,87,88]}$ & N361-411 & $90 \%$ \\
\hline M1-31 $1^{[83,84]}$ & M1-32 & $93 \%$ \\
\hline M132-161 $1^{[84]}$ & M133-162 & $90 \%$ \\
\hline M165-176 $6^{[83]}$ & M166-177 & $100 \%$ \\
\hline M173-185 & $174-186$ & $100 \%$ \\
\hline M207-221 [90] & M208-222 & $80 \%$ \\
\hline
\end{tabular}

\section{Acknowledgements}

Lluc Farrera-Soler is grateful to the Swiss Chemical Society and Metrohm for the best oral presentation award in Medicinal Chemistry and Chemical Biology. This work has been supported by the Swiss National Science Foundation (SNF).

Received: January 29, 2021 
[1] J. Cohen, D. Normile, Science https://doi.org/10.1126/science.367.6475.234

[2] M. Nicola, Z. Alsafi, C. Sohrabi, A. Kerwan, A. Al-Jabir, C. Iosifidis, M. Agha, R. Agha, Int. J. Surg. 2020, 78, 185, https://doi.org/10.1016/j.ijsu.2020.04.018

[3] R. J. Lu, X. Zhao, J. Li, P. H. Niu, B. Yang, H. L. Wu, W. L. Wang, H Song, B. Y. Huang, N. Zhu, Y. H. Bi, X. J. Ma, F. X. Zhan, L. Wang, T. Hu, H. Zhou, Z. H. Hu, W. M. Zhou, L. Zhao, J. Chen, Y. Meng, J. Wang, Y. Lin, J. Y. Yuan, Z. H. Xie, J. M. Ma, W. J. Liu, D. Y. Wang, W. B. Xu, E. C. Holmes, G. F. Gao, G. Z. Wu, W. J. Chen, W. F. Shi, W. J. Tan, Lancet 2020, 395, 565, https://doi.org/10.1016/S0140-6736(20)30251-8.

[4] C. Drosten, S. Gunther, W. Preiser, S. van der Werf, H. R. Brodt, S Becker, H. Rabenau, M. Panning, L. Kolesnikova, R. A. M. Fouchier, A. Berger, A. M. Burguiere, J. Cinatl, M. Eickmann, N. Escriou, K. Grywna, S. Kramme, J. C. Manuguerra, S. Muller, V. Rickerts, M. Sturmer, S. Vieth, H. D. Klenk, A. D. M. E. Osterhaus, H. Schmitz, H. W. Doerr, New Engl. J. Med. 2003, 348, 1967, https://doi.org/10.1056/NEJMoa030747.

[5] M. Hoffmann, H. Kleine-Weber, S. Schroeder, N. Kruger, T. Herrler, S. Erichsen, T. S. Schiergens, G. Herrler, N. H. Wu, A. Nitsche, M. A. Muller, C. Drosten, S. Pohlmann, Cell 2020, 181, 271, https://doi.org/10.1016/j.cell.2020.02.052

[6] R. H. Yan, Y. Y. Zhang, Y. N. Li, L. Xia, Y. Y. Guo, Q. Zhou, Science 2020, 367, 1444, https://doi.org/10.1126/science.abb2762.

[7] Y. He, Y. Zhou, S. Liu, Z. Kou, W. Li, M. Farzan, S. Jiang, Biochem. Bioph. Res. Commun. 2004, 324, 773, https://doi.org/10.1016/j.bbrc.2004.09.106.

[8] Y. Galipeau, M. Greig, G. Liu, M. Driedger, M.-A. Langlois, Front. Immunol. 2020, 11, https://doi.org/10.3389/fimmu.2020.610688.

[9] X. Y. Che, L. W. Qiu, Z. Y. Liao, Y. D. Wang, K. Wen, Y. X. Pan, W. Hao, Y. B. Mei, Vincent, K. Y. Yuen, J. Infect. Dis. 2005, 191, 2033, https://doi.org/10.1086/430355.

[10] H. W. Jiang, Y. Li, H. N. Zhang, W. Wang, X. Yang, H. Qi, H. Li, D. Men, J. Zhou, S. C. Tao, Nat. Commun. 2020, 11, https://doi.org/10.1038/s41467-020-17488-8.

[11] N. J. Andersen, T. K. Mondal, M. T. Preissler, B. M. Freed, S. Stockinger, E. Bell, C. Druschel, G. M. Buck Louis, D. A. Lawrence, J. Immunol. Meth. 2014, 404, 24, https://doi.org/10.1016/j.jim.2013.12.001

[12] M. Jorfi, N. M. Luo, A. Hazra, F. Herisson, G. Miller, J. A. Toombs, D. R. Walt, P. Bonato, R. Ahmad, medRxiv 2020, 2020.06.25.20140236, https://doi.org/10.1101/2020.06.25.20140236.

[13] K. Heiss, J. Heidepriem, N. Fischer, L. K. Weber, C. Dahlke, T. Jaenisch, F. F. Loeffler, J. Proteome Res. 2020, 19, 4339, https://doi.org/10.1021/acs.jproteome.0c00484.

[14] M. W. Heuzenroeder, M. D. Barton, T. Vanniasinkam, T. Phumoonna, in 'Epitope Mapping Protocols', Humana Press, 2009, p. 137, https://doi.org/10.1007/978-1-59745-450-6_10.

[15] V. Böttger, A. Böttger, 'Epitope mapping using phage display peptide libraries', Vol. 524, Humana Press, Methods in Molecular Biology ${ }^{\mathrm{TM}}$ (Methods and Protocols), 2009

[16] W. Decurtins, M. Wichert, R. M. Franzini, F. Buller, M. A. Stravs, Y. Zhang, D. Neri, J. Scheuermann, Nat. Protoc. 2016, 11, 764, https://doi.org/10.1038/nprot.2016.039.

[17] G. Zimmermann, D. Neri, Drug Discov. Today 2016, 21, 1828 , https://doi.org/10.1016/j.drudis.2016.07.013.

[18] H. Wang, X. Wu, X. Zhang, X. Hou, T. Liang, D. Wang, F. Teng, J. Dai, H. Duan, S. Guo, Y. Li, X. Yu, ACS Cent. Sci. 2020, 6, 2238, https://doi.org/10.1021/acscentsci.0c00742.

[19] X. Zhang, X. Wu, D. Wang, M. Lu, X. Hou, H. Wang, T. Liang, J. Dai, H. Duan, Y. Xu, Y. Li, X. Yu, medRxiv 2020, 2020.04.14.20064535, https://doi.org/10.1101/2020.04.14.20064535

[20] Y. Li, D. Y. Lai, H. N. Zhang, H. W. Jiang, X. L. Tian, M. L. Ma, H. Qi Q. F. Meng, S. J. Guo, Y. L. Wu, W. Wang, X. Yang, D. W. Shi, J. B. Dai, T. L. Ying, J. Zhou, S. C. Tao, Cell Mol. Immunol. 2020, 17, 1095 , https://doi.org/10.1038/s41423-020-00523-5.

[21] Y. Li, M.-1. Ma, Q. Lei, F. Wang, D.-y. Lai, H. Hou, Z.-w. Xu, B. Zhang, H. Chen, C. Yu, J.-b. Xue, Y.-X. Zheng, X.-n. Wang, H.-w. Jiang, H.-n. Zhang, H. Qi, S.-j. Guo, Y. Zhang, X. Lin, Z. Yao, J. Wu, H. Sheng, Z. Sun, X. Fan, S.-c. Tao, medRxiv 2020, 2020.07.13.20152587, https://doi.org/10.1101/2020.07.13.20152587.

[22] Y. Li, D.-y. Lai, Q. Lei, Z.-w. Xu, F. Wang, H. Hou, L. Chen, J. Wu, Y. Ren, M.-1. Ma, B. Zhang, H. Chen, C. Yu, J.-b. Xue, Y.-X. Zheng, X.-n. Wang, H.-w. Jiang, H.-n. Zhang, H. Qi, S.-j. Guo, Y. Zhang, X. Lin, Z. Yao, P. Pang, D. Shi, W. Wang, X. Yang, J. Zhou, H. Sheng, Z. Sun, H. Shan, X. Fan, S.-c. Tao, Cell Mol. Immunol. 2021, https://doi.org/10.1038/s41423-020-00612-5.

[23] L. Farrera-Soler, J. P. Daguer, S. Barluenga, O. Vadas, P. Cohen, S. Pagano, S. Yerly, L. Kaiser, N. Vuilleumier, N. Winssinger, Plos One 2020, 15, https://doi.org/ARTNe023808910.1371/journal.pone.0238089.

[24] A. Musicò, R. Frigerio, A. Mussida, L. Barzon, A. Sinigaglia, S. Riccetti, F. Gobbi, C. Piubelli, G. Bergamaschi, M. Chiari, A. Gori, M. Cretich, Vaccines 2021, 9, 35, https://doi.org/10.3390/vaccines 9010035
[25] N. Mishra, X. Huang, S. Joshi, C. Guo, J. Ng, R. Thakkar, Y. Wu, X. Dong, Q. Li, R. Pinapati, E. Sullivan, A. Caciula, R. Tokarz, T. Briese, J. Lu, W. I. Lipkin, bioRxiv 2020, 2020.08.13.249953, https://doi.org/10.1101/2020.08.13.249953

[26] P. Holenya, P. J. Lange, U. Reimer, W. Woltersdorf, T. Panterodt, M. Glas, M. Wasner, M. Eckey, M. Drosch, J.-M. Hollidt, M. Naumann, F. Kern, H. Wenschuh, R. Lange, K. Schnatbaum, F. F. Bier, medRxiv 2020, 2020.11.24.20216663, https://doi.org/10.1101/2020.11.24.20216663.

[27] A. S. Heffron, S. J. McIlwain, M. F. Amjadi, D. A. Baker, S. Khullar, A. K. Sethi, A. C. Palmenberg, M. A. Shelef, D. H. O'Connor, I. M. Ong, bioRxiv 2021, 2020.10.10.334292, https://doi.org/10.1101/2020.10.10.334292.

[28] D. Camerini, A. Z. Randall, K. Trappl-Kimmons, A. Oberai, C. Hung, J. Edgar, A. Shandling, V. Huynh, A. A. Teng, G. Hermanson, J. V. Pablo, M. M. Stumpf, S. N. Lester, J. Harcourt, A. Tamin, M. Rasheed, N. J. Thornburg, P. S. Satheshkumar, X. Liang, R. B. Kennedy, A. Yee, M. Townsend, J. J. Campo, medRxiv 2021, 2021.01.14.21249690, https://doi.org/10.1101/2021.01.14.21249690.

[29] Z. G. Yi, Y. Ling, X. N. Zhang, J. L. Chen, K. Y. Hu, Y. Y. Wang, W. H. Song, T. L. Ying, R. Zhang, H. Z. Lu, Z. H. Yuan, Emerg. Microbes Infect. 2020, 9, 1988, https://doi.org/10.1080/22221751.2020.1815591.

[30] C. Dahlke, J. Heidepriem, R. Kobbe, R. Santer, T. Koch, A. Fathi, M. L. Ly, S. Schmiedel, P. H. Seeberger, M. M. Addo, F. F. Loeffler, medRxiv 2020, 2020.04.14.20059733, https://doi.org/10.1101/2020.04.14.20059733.

[31] C. M. Poh, G. Carissimo, B. Wang, S. N. Amrun, C. Y. P. Lee, R. S. L. Chee, S. W. Fong, N. K. W. Yeo, W. H. Lee, A. TorresRuesta, Y. S. Leo, M. I. C. Chen, S. Y. Tan, L. Y. A. Chai, S. Kalimuddin, S. S. G. Kheng, S. Y. Thien, B. E. Young, D. C. Lye, B J. Hanson, C. I. Wang, L. Renia, L. F. P. Ng, Nat. Commun. 2020, 11, https://doi.org/ARTN280610.1038/s41467-020-16638-2.

[32] S. N. Amrun, C. Y. P. Lee, B. E. Lee, S. W. Fong, B. E. Young, R. S. L. Chee, N. K. W. Yeo, A. Torres-Ruesta, G. Carissimo, C. M. Poh, Z. W. Chang, M. Z. Tay, Y. H. Chan, M. I. C. Chen, J. G. H. Low, P. A. Tambyah, S. Kalimuddin, S. Pada, S. Y. Tan, L. J. Sun, Y. S. Leo, D. C. Lye, L. Renia, L. F. P. Ng, Ebiomedicine 2020, 58, https://doi.org/ARTN10291110.1016/j.ebiom.2020.102911.

[33] B. Z. Zhang, Y. F. Hu, L. L. Chen, T. Yau, Y. G. Tong, J. C. Hu, J. P. Cai, K. H. Chan, Y. Dou, J. Deng, X. L. Wang, I. F. N. Hung, K. K. W. To, K. Y. Yuen, J. D. Huang, Cell Res. 2020, 30, 702, https://doi.org/10.1038/s41422-020-0366-X.

[34] J. T. Ladner, S. N. Henson, A. S. Boyle, A. L. Engelbrektson, Z. W. Fink, F. Rahee, J. D'ambrozio, K. E. Schaecher, M. Stone, W. Dong, S. Dadwal, J. Yu, M. A. Caligiuri, P. Cieplak, M. Bjørås, M. H. Fenstad, S. A. Nordb $\varnothing$, D. E. Kainov, N. Muranaka, M. S. Chee, S. A. Shiryaev, J. A. Altin, bioRxiv 2020, 2020.07.27.222943, https://doi.org/10.1101/2020.07.27.222943.

[35] H. B. Larman, Z. M. Zhao, U. Laserson, M. Z. Li, A. Ciccia, M. A. M. Gakidis, G. M. Church, S. Kesari, E. M. LeProust, N. L. Solimini, S. J. Elledge, Nat. Biotechnol. 2011, 29, 535, https://doi.org/10.1038/nbt.1856.

[36] D. Mohan, D. L. Wansley, B. M. Sie, M. S. Noon, A. N. Baer, U. Laserson, H. B. Larman, Nat. Protoc. 2018, 13, 1958 , https://doi.org/10.1038/s41596-018-0025-6.

[37] K. Kamath, J. Reifert, T. Johnston, C. Gable, R. J. Pantazes, H. N. Rivera, I. McAuliffe, S. Handali, P. S. Daugherty, Sci. Rep. 2020, 10, https://doi.org/ARTN529410.1038/s41598-020-62256-9.

[38] H. Qi, M. Ma, C. Hu, Z.-W. Xu, F.-L. Wu, N. Wang, D.-Y. Lai, Y. Li, S.-J. Guo, X. Zhao, H. Li, S.-C. Tao,,, Cold Spring Harbor Laboratory, 2019, https://www.sciencedirect.com/science/article/pii/ S1535947621000323?via\%3Dihub.

[39] E. Shrock, E. Fujimura, T. Kula, R. T. Timms, I. H. Lee, Y. M. Leng, M. L. Robinson, B. M. Sie, M. Z. Li, Y. Z. Chen, J. Logue, A. Zuiani, D. McCulloch, F. J. N. Lelis, S. Henson, D. R. Monaco, M. Travers, S. Habibi, W. A. Clarke, P. Caturegli, O. Laeyendecker, A. Piechocka-Trocha, J. Z. Li, A. Khatri, H. Y. Chu, A. C. Villani, K. Kays, M. B. Goldberg, N. Hacohen, M. R. Filbin, X. G. Yu, B. D. Walker, D. R. Wesemann, H. B. Larman, J. A. Lederer, S. J. Elledge, M. C. D.-C. P. Team, Science 2020, 370, 1058, https://doi.org/ARTNeabd425010.1126/science.abd4250.

[40] L. Wang, J. Candia, L. Ma, Y. Zhao, L. Imberti, A. Sottini, K. Dobbs, A. Lisco, I. Sereti, H. C. Su, L. D. Notarangelo, X. W. Wang, medRxiv 2020 , 2020.09.04.20187088, https://doi.org/10.1101/2020.09.04.20187088

[41] H. Qi, M.-1. Ma, J. Jiang, J.-y. Ling, L.-y. Chen, H.-n. Zhang, D.-y. Lai, Y. Li, Z.-w. Guo, C.-s. Hu, S.-j. Guo, Q.-f. Meng, Y. Ren, W. Wang, X. Yang, J. Zhou, X.-d. Zhao, H. Li, S.-c. Tao, medRxiv 2020, 2020.09.08.20190496, https://doi.org/10.1101/2020.09.08.20190496.

[42] S. Klompus, S. Leviatan, T. Vogl, I. Kalka, A. Godneva, E. Shinar, A. Weinberger, E. Segal, medRxiv 2020, 2020.09.01.20182220, https://doi.org/10.1101/2020.09.01.20182220.

[43] W. A. Haynes, K. Kamath, J. Bozekowski, E. Baum-Jones, M. Campbell, A. Casanovas-Massana, P. S. Daugherty, C. S. Dela Cruz, A. Dhal, S. F. Farhadian, L. Fitzgibbons, J. Fournier, M. Jhatro, G. Jordan, D. Kessler, J. Klein, C. Lucas, L. L. Luchsinger, B. Martinez, M. C. Muenker, L. Pischel, J. Reifert, J. R. Sawyer, R. Waitz, E. A. Wunder, M. Zhang, 
A. Iwasaki, A. I. Ko, J. C. Shon, medRxiv 2020, 2020.11.23.20235002, https://doi.org/10.1101/2020.11.23.20235002.

[44] C. R. Zamecnik, J. V. Rajan, K. A. Yamauchi, S. A. Mann, R. P. Loudermilk, G. M. Sowa, K. C. Zorn, B. D. Alvarenga, C. Gaebler, M. Caskey, M. Stone, P. J. Norris, W. Gu, C. Y. Chiu, D. Ng, J. R. Byrnes, X. X. Zhou, J. A. Wells, D. F. Robbiani, M. C. Nussenzweig, J. L. DeRisi, M. R. Wilson, Cell Rep. Med. 2020, 1, 100123, https://doi.org/10.1016/j.xcrm.2020.100123.

[45] Y. Watanabe, J. D. Allen, D. Wrapp, J. S. McLellan, M. Crispin, Science 2020, 369, 330, https://doi.org/10.1126/science.abb9983.

[46] M. Yuan, H. Liu, N. C. Wu, I. A. Wilson, Biochem. Biophys. Res. Commun. 2020, https://doi.org/10.1016/j.bbrc.2020.10.012.

[47] C. Kim, D.-K. Ryu, J. Lee, Y.-I. Kim, J.-M. Seo, Y.-G. Kim, J.-H. Jeong, M. Kim, J.-I. Kim, P. Kim, J. S. Bae, E. Y. Shim, M. S. Lee, M. S. Kim, H. Noh, G.-S. Park, J. S. Park, D. Son, Y. An, J. N. Lee, K.-S. Kwon, J.-Y. Lee, H. Lee, J.-S. Yang, K.-C. Kim, S. S. Kim, H.-M. Woo, J.-W. Kim, M.-S. Park, K.-M. Yu, S.-M. Kim, E.-H. Kim, S.-J. Park, S. T. Jeong, C. H. Yu, Y. Song, S. H. Gu, H. Oh, B.-S. Koo, J. J. Hong, C.-M. Ryu, W. B. Park, M.-D. Oh, Y. K. Choi, S.-Y. Lee, Nat. Commun. 2021, 12, https://doi.org/10.1038/s41467-020-20602-5.

[48] C. O. Barnes, C. A. Jette, M. E. Abernathy, K.-M. A. Dam, S. R. Esswein, H. B. Gristick, A. G. Malyutin, N. G. Sharaf, K. E. Huey-Tubman, Y E. Lee, D. F. Robbiani, M. C. Nussenzweig, A. P. West, P. J. Bjorkman, Nature 2020, 588, 682, https://doi.org/10.1038/s41586-020-2852-1.

[49] Y. Wu, F. R. Wang, C. G. Shen, W. Y. Peng, D. L. Li, C. Zhao, Z. H. Li, S. H. Li, Y. H. Bi, Y. Yang, Y. H. Gong, H. X. Xiao, Z. Fan, S. G. Tan, G. Z. Wu, W. J. Tan, X. C. Lu, C. F. Fan, Q. H. Wang, Y. X. Liu, C. Zhang, J. X. Qi, G. F. Gao, F. Gao, L. Liu, Science 2020, 368, 1274, https://doi.org/10.1126/science.abc2241.

[50] L. Premkumar, B. Segovia-Chumbez, R. Jadi, D. R. Martinez, R. Raut, A. J. Markmann, C. Cornaby, L. Bartelt, S. Weiss, Y. Park, C. E. Edwards, E. Weimer, E. M. Scherer, N. Rouphael, S. Edupuganti, D. Weiskopf, L. V. Tse, Y. X. J. Hou, D. Margolis, A. Sette, M. H. Collins, J. Schmitz, R. S. Baric, A. M. de Silva, Sci. Immunol. 2020, 5 , https://doi.org/ARTNeabc841310.1126/sciimmunol.abc8413.

[51] M. Hoffmann, H. Kleine-Weber, S. Pohlmann, Mol. Cell 2020, 78, 779 , https://doi.org/10.1016/j.molcel.2020.04.022.

[52] B. A. Johnson, X. Xie, A. L. Bailey, B. Kalveram, K. G. Lokugamage, A. Muruato, J. Zou, X. Zhang, T. Juelich, J. K. Smith, L. Zhang, N. Bopp, C. Schindewolf, M. Vu, A. Vanderheiden, E. S. Winkler, D. Swetnam, J. A. Plante, P. Aguilar, K. S. Plante, V. Popov, B. Lee, S. C Weaver, M. S. Suthar, A. L. Routh, P. Ren, Z. Ku, Z. An, K. Debbink, M. S. Diamond, P. Y. Shi, A. N. Freiberg, V. D. Menachery, Nature 2021, https://doi.org/10.1038/s41586-021-03237-4.

[53] Y. Huang, C. Yang, X. F. Xu, W. Xu, S. W. Liu, Acta Pharmacol. Sin. 2020, 41, 1141, https://doi.org/10.1038/s41401-020-0485-4.

[54] M. Kawase, M. Kataoka, K. Shirato, S. Matsuyama, J. Virol. 2019, 93, https://doi.org/ARTNe00785-1910.1128/JVI.00785-19.

[55] T. Miyoshi-Akiyama, I. Ishida, M. Fukushi, K. Yamaguchi, Y. Matsuoka, T. Ishihara, M. Tsukahara, S. Hatakeyama, N. Itoh, A. Morisawa, Y. Yoshinaka, N. Yamamoto, L. F. Zhang, C. A. Qin, T. Kirikae, T. Sasazuki, J. Infect. Dis. 2011, 203, 1574, https://doi.org/10.1093/infdis/jir084.

[56] S. W. Liu, G. F. Xiao, Y. B. Chen, Y. X. He, J. K. Niu, C. R. Escalante, H. B. Xiong, J. Farmar, A. K. Debnath, P. Tien, S. B. Jiang, Lancet 2004, 363, 938, https://doi.org/10.1016/S0140-6736(04)15788-7.

[57] C. Wang, C. Hua, S. Xia, W. H. Li, L. Lu, S. B. Jiang, Viruses 2019, 11 , https://doi.org/ARTN3110.3390/v11010031.

[58] S. Xia, Q. S. Lan, J. Pu, C. Wang, Z. Z. Liu, W. Xu, Q. Wang, H. Liu, S. B. Jiang, L. Lu, Viruses 2019, 11, https://doi.org/ARTN 5610.3390/v11010056.

[59] S. Xia, M. Q. Liu, C. Wang, W. Xu, Q. S. Lan, S. L. Feng, F. F. Qi, L. L. Bao, L. Y. Du, S. W. Liu, C. Qin, F. Sun, Z. L. Shi, Y. Zhu, S. B. Jiang, L. Lu, Cell Res. 2020, 30, 343, https://doi.org/10.1038/s41422-020-0305-x.

[60] C. Wang, C. Hua, S. Xia, W. Li, L. Lu, S. Jiang, Viruses 2019, 11, 31, https://doi.org/10.3390/v11010031

[61] S. C. Lai, P. C. S. Chong, C. T. Yeh, L. S. J. Liu, J. T. Jan, H. Y. Chi, H. W. Liu, A. Chen, Y. C. Wang, J. Biomed. Sci. 2005, 12, 711, https://doi.org/10.1007/s11373-005-9004-3.

[62] C. T. Keng, A. Zhang, S. Shen, K. M. Lip, B. C. Fielding, T H. P. Tan, C. F. Chou, C. B. Loh, S. F. Wang, J. L. Fu, X. M Yang, S. G. Lim, W. J. Hong, Y. J. Tan, J. Virol. 2005, 79, 3289, https://doi.org/10.1128/Jvi.79.6.3289-3296.2005.

[63] K. M. Lip, S. Shen, X. M. Yang, C. T. Keng, A. H. Zhang, H. L. J. Oh, Z. H. Li, L. A. Hwang, C. F. Chou, B. C. Fielding, T. H. P. Tan, J. Mayrhofer, F. G. Falkner, J. L. Fu, S. G. Lim, W. J. Hong, Y. J. Tan, J. Virol. 2006, 80, 941, https://doi.org/10.1128/Jvi.80.2.941-950.2006

[64] H. A. Elshabrawy, M. M. Coughlin, S. C. Baker, B. S. Prabhakar, Plos One 2012, 7, https://doi.org/ARTNe5036610.1371/journal.pone.0050366.

[65] M. F. Qiu, Y. L. Shi, Z. B. Guo, Z. L. Chen, R. Q. He, R. S. Chen, D. S. Zhou, E. H. Dai, X. Y. Wang, B. Y. Si, Y. J. Song, J. X. Li, L. Yang, J. Wang, H. X. Wang, X. Pang, J. H. Zhai, Z. M. Du, Y. Liu, Y. Zhang,
L. H. Li, J. Wang, B. Sun, R. F. Yang, Microbes Infect. 2005, 7, 882 https://doi.org/10.1016/j.micinf.2005.02.006.

[66] A. Algaissi, M. A. Alfaleh, S. Hala, T. S. Abujamel, S. S. Alamri, S. A. Almahboub, K. A. Alluhaybi, H. I. Hobani, R. M. Alsulaiman, R. H. AlHarbi, M. Z. A. ElAssouli, R. Y. Alhabbab, A. A. AlSaieedi, W. H Abdulaal, A. A. Al-Somali, F. S. Alofi, A. A. Khogeer, A. A. Alkayyal, A. B. Mahmoud, N. A. M. Almontashiri, A. Pain, A. M. Hashem, Sci. Rep. 2020, 10, https://doi.org/RTN 1656110.1038/s41598-020-73491-5.

[67] R. Kubina, A. Dziedzic, Diagnostics 2020, 10 https://doi.org/ARTN 43410.3390/diagnostics10060434.

[68] A. C. R. Hoste, A. Venteo, A. Fresco-Taboada, I. Tapia, A. Monedero, L. Lopez, M. F. Jebbink, E. Perez-Ramirez, M. A. JimenezClavero, M. Almonacid, P. Munoz, J. Guinea, C. Vela, L. van der Hoek, P. Rueda, P. Sastre, Diagn. Micr. Infec. Dis. 2020, 98, https://doi.org/ARTN11516710.1016/j.diagmicrobio.2020.115167.

[69] Z. Elgundi, M. Reslan, E. Cruz, V. Sifniotis, V. Kayser, Adv. Drug Deliver. Rev. 2017, 122, 2, https://doi.org/10.1016/j.addr.2016.11.004.

[70] S. Jiang, X. Zhang, Y. Yang, P. J. Hotez, L. Du, Nature Biomed. Engin. 2020, 4, 1134, https://doi.org/10.1038/s41551-020-00660-2.

[71] L. S. Wang, W. Shi, J. D. Chappell, M. G. Joyce, Y. Zhang, M. Kanekiyo, M. M. Becker, N. van Doremalen, R. Fischer, N. S. Wang, K. S. Corbett, M. Choe, R. D. Mason, J. G. Van Galen, T. Q. Zhou, K. O. Saunders, K. M. Tatti, L. M. Haynes, P. D. Kwong, K. Modjarrad, W. P. Kong, J. S. McLellan, M. R. Denison, V. J. Munster, J. R. Mascola, B. S. Graham, J. Virol. 2018, 92, https://doi.org/ARTNe02002-1710.1128/JVI.02002-17.

[72] D. Li, J. Li, J. Clin. Microbiol. 2020, JCM.02160, https://doi.org/10.1128/jcm.02160-20.

[73] K. Hoelzle, J. Grimm, M. Ritzmann, K. Heinritzi, P. Torgerson, A Hamburger, M. M. Wittenbrink, L. E. Hoelzle, Clin. Vaccine Immunol. 2007, 14, 1616, https://doi.org/10.1128/Cvi.00345-07.

[74] X.-y. Che, L.-w. Qiu, Z.-y. Liao, Y.-d. Wang, K. Wen, Y.-x. Pan, W. Hao, Y.-b. Mei, V. C. C. Cheng, K.-y. Yuen, J. Infect. Dis. 2005, 191, 2033, https://doi.org/10.1086/430355.

[75] S. Isabel, L. Graña-Miraglia, J. M. Gutierrez, C. Bundalovic-Torma, H. E. Groves, M. R. Isabel, A. Eshaghi, S. N. Patel, J. B. Gubbay, T. Poutanen, D. S. Guttman, S. M. Poutanen, Sci. Rep. 2020, 10 https://doi.org/10.1038/s41598-020-70827-z.

[76] B. Korber, W. M. Fischer, S. Gnanakaran, H. Yoon, J. Theiler, W Abfalterer, N. Hengartner, E. E. Giorgi, T. Bhattacharya, B. Foley, K. M. Hastie, M. D. Parker, D. G. Partridge, C. M. Evans, T. M. Freeman, T. I. De Silva, C. McDanal, L. G. Perez, H. Tang, A. Moon-Walker, S. P. Whelan, C. C. Labranche, E. O. Saphire, D. C. Montefiori, A. Angyal, R. L. Brown, L. Carrilero, L. R. Green, D. C. Groves, K. J. Johnson, A. J. Keeley, B. B. Lindsey, P. J. Parsons, M. Raza, S. Rowland-Jones, N. Smith, R. M. Tucker, D. Wang, M. D. Wyles, Cell 2020, 182, 812, https://doi.org/10.1016/j.cell.2020.06.043.

[77] R. Lassaunière, J. Fonager, M. Rasmussen, A. Frische, C. P. Strandh, T. B. Rasmussen, A. B $\varnothing$ tner, A. Fomsgaard, 'SARS-CoV-2 spike mutations arising in Danish mink and their spread to 5 humans', 2020.

[78] A. Rambaut, N. Loman, O. G. Pybus, W. Barclay, J. Barrett, A. Carabelli, T. Connor, T. Peacock, D. L. Robertson, E. Volz, in 'Virological.org', https://virological.org/t/preliminary-genomic-characterisation-of-anemergent-sars-cov-2-lineage-in-the-uk-defined-by-a-novel-set-of-spikemutations $/ 563,2020$

[79] H. Tegally, E. Wilkinson, M. Giovanetti, A. Iranzadeh, V. Fonseca, J. Giandhari, D. Doolabh, S. Pillay, E. J. San, N. Msomi, K. Mlisana, A von Gottberg, S. Walaza, M. Allam, A. Ismail, T. Mohale, A. J. Glass, S. Engelbrecht, G. Van Zyl, W. Preiser, F. Petruccione, A. Sigal, D. Hardie, G. Marais, M. Hsiao, S. Korsman, M.-A. Davies, L. Tyers, I. Mudau, D. York, C. Maslo, D. Goedhals, S. Abrahams, O. Laguda-Akingba, A. AlisoltaniDehkordi, A. Godzik, C. K. Wibmer, B. T. Sewell, J. Lourenço, L. C. J. Alcantara, S. L. K. Pond, S. Weaver, D. Martin, R. J. Lessells, J. N. Bhiman, C. Williamson, T. de Oliveira, medRxiv 2020, 2020.12.21.20248640, https://doi.org/10.1101/2020.12.21.20248640.

[80] National Institute of Infectious Diseases, https://www.niid.go.jp/niid/ja/diseases/ka/corona-virus/2019-ncov/10107-covid19-33.html, 2021.

[81] W. Zhang, B. Davis, S. S. Chen, J. Sincuir Martinez, J. T. Plummer, E. Vail, medRxiv 2021, 2021.01.18.21249786, https://doi.org/10.1101/2021.01.18.21249786.

[82] W. A. Haynes, K. Kamath, C. Lucas, J. Shon, A. Iwasaki, medRxiv 2021, 2021.01.06.20248960, https://doi.org/10.1101/2021.01.06.20248960.

[83] J. P. Guo, M. Petric, W. Campbell, P. L. McGeer, Virology 2004, 324, 251, https://doi.org/10.1016/j.virol.2004.04.017

[84] Y. X. He, Y. S. Zhou, P. Siddiqui, J. K. Niu, S. B. Jiang, J. Clin. Microbiol. 2005, 43, 3718, https://doi.org/10.1128/Jcm.43.8.3718-3726.2005.

[85] Y. X. He, Y. S. Zhou, H. Wu, Z. H. Kou, S. W. Liu, S. B. Jiang, J. Clin. Microbiol. 2004, 42, 5309, https://doi.org/10.1128/Jcm.42.11.5309-5314.2004.

[86] Y. X. He, Y. S. Zhou, H. Wu, B. J. Luo, J. M. Chen, W. B. Li, S. B Jiang, J. Immunol. 2004, 173, 4050, https://doi.org/10.4049/jimmunol.173.6.4050 
[87] H. Hu, L. Li, R. Y. Kao, B. Kou, Z. Wang, L. Zhang, H. Zhang, Z. Hao, W. H. Tsui, A. Ni, L. Cui, B. Fan, F. Guo, S. Rao, C. Jiang, Q. Li, M. Sun, W. He, G. Liu, J. Combin. Chem. 2005, 7, 648, https://doi.org/10.1021/cc0500607.

[88] S. Li, L. Lin, H. Wang, J. Yin, Y. Ren, Z. Zhao, J. Wen, C. Zhou, X. Zhang, X. Li, J. Wang, Z. Zhou, J. Liu, J. Shao, T. Lei, J. Fang, N. Xu, S. Liu, Genomics, Proteomics \& Bioinformatics 2003, 1, 198, https://doi.org/ https://doi.org/10.1016/S1672-0229(03)01025-8.

[89] Y. Ren, Z. Zhou, J. Liu, L. Lin, S. Li, H. Wang, J. Xia, Z. Zhao, J. Wen, C. Zhou, J. Wang, J. Yin, N. Xu, S. Liu, Genomics, Proteomics \& Bioinformatics 2003, 1, 207, https://doi.org/https://doi.org/10.1016/S1672-0229(03)01026-X.

[90] S. Shichijo, N. Keicho, H. T. Long, T. Quy, N. C. Phi, L. D. Ha, V. V. Ban, S. Itoyama, C. J. Hu, N. Komatsu, T. Kirikae, F. Kirikae, S. Shirasawa, M. Kaji, T. Fukuda, M. Sata, T. Kuratsuji, K. Itoh, T. Sasazuki, Tissue Antigens 2004, 64, 600, https://doi.org/10.1111/j.1399-0039.2004.00314.x.

[91] H. Yu, L. F. Jiang, D. Y. Fang, H. J. Yan, J. J. Zhou, J. M. Zhou, Y. Liang, Y. Gao, W. Zhao, B. G. Long, Virology 2007, 359, 264, https://doi.org/10.1016/j.virol.2006.09.016.
[92] X. Zhong, H. Yang, Z.-F. Guo, W.-Y. F. Sin, W. Chen, J. Xu, L. Fu, J. Wu, C.-K. G. Mak, C.-S. S. Cheng, Y. Yang, S. Cao, T.Y. Wong, S.-T. Lai, Y. Xie, Z. Guo, J. Virol. 2005, 79, 3401, https://doi.org/10.1128/jvi.79.6.3401-3408.2005.

\section{License and Terms}

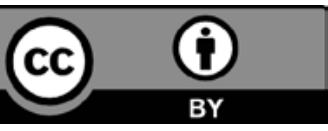

This is an Open Access article under the terms of the Creative Commons Attribution License CC BY 4.0. The material may not be used for commercial purposes.

The license is subject to the CHIMIA terms and conditions: (http:// chimia.ch/component/sppagebuilder/?view=page \&id=12).

The definitive version of this article is the electronic one that can be found at https://doi.org/10.2533/chimia.2021.276 